\title{
The quality of rainwater collected from roofs in the aspect of the possibility of their economic use
}

\author{
Monika M. Zdeb ${ }^{1}$, Justyna Zamorska ${ }^{1}$, Dorota Papciak ${ }^{1}$, Daniel Słyś ${ }^{2}$ \\ ${ }^{1}$ Department of Water Purification and Protection, Rzeszow University of Technology, al. Powstancow Warszawy 6, 35-959 \\ 5 Rzeszow, Poland \\ ${ }^{2}$ Department of Infrastructure and Sustainable Development, Rzeszow University of Technology, al. Powstancow Warszawy \\ 6, 35-959 Rzeszow, Poland
}

Correspondence to: Monika M. Zdeb (mzdeb@prz.edu.pl)

Abstract. The large variability in rainwater quality both in time and location as well as the relatively small number of tests make the preliminary assessment of economic exploitation of these waters difficult. Determining the relation between the conditions and location of rainwater collection and rainwater quality would help to indicate the range of options for rainwater use as well as parameters that require improvement.

The aim of the presented article is to establish chosen physical, chemical and microbiological parameters of rainwater and, based on the results obtained, to determine the possibilities for a safe use of these waters in households. The research had been

15 carried out for two years. Samples of chosen rainfalls were collected from spring to autumn from the following roofing materials: concrete roof tiles, ceramic roof tiles, zinc coated metal sheets and epoxy coated. The physical, chemical and microbiological quality assessment has been conducted basing on the following parameters: reaction, turbidity, electrical conductivity, concentration of biogenic compounds, concentration of chosen elements, number of Escherichia coli as well as number faecal streptococci.

20 A significant bacterial contamination, a decreased $\mathrm{pH}$ and an increased turbidity of rainwaters were identified, depending on the parameters of the roofing washed by rainfalls and the intensity and frequency of precipitation.

\section{Introduction}

Currently, approximately $36 \%$ of the world's population face a water crisis. In many areas, it is not possible to satisfy the increasing demand for this resource, due to a restricted access to freshwater supplies. It is believed that countries with water resources below $2000 \mathrm{~m}^{3} \cdot \mathrm{M}^{-1}$ may face difficulties addressing the needs of their population, while countries with resources below $1000 \mathrm{~m}^{3} \cdot \mathrm{M}^{-1}$ are considered as areas with a severe water deficit.

In Poland, the biggest problem of water management is a major variability of atmospheric precipitations as well as extreme hydrologic phenomena, particularly apparent in large agglomerations and in rural areas (Pierzgalski et al. 2012, Kundziewicz et al. 2010). 
Hydrol. Earth Syst. Sci. Discuss., https://doi.org/10.5194/hess-2019-117

Manuscript under review for journal Hydrol. Earth Syst. Sci.

Discussion started: 29 April 2019

The analysis of the domestic water consumption structure shows that approximately $50 \%$ of potable water can be substituted by rainwater, while in public buildings this value is almost 65\% (Ludwińska and Paduchowska, 2017). Rainwater harvesting and storage systems have been implemented in several countries. Water collected in this way is a valuable source of freshwater, which can reduce the demand for tap water and which can be used during periods of drought (Słyś, 2013). Rainwater harvesting

5 technologies are used worldwide to support drinking water supplies (Zhang et al., 2009, Jones and Hunt, 2010), rainwater management and flood risk reduction by reducing the volume of water flows in storm drainage systems (Słyś and Stec, 2012). These technologies constitute also one of the elements of an efficient and environmentally sound functioning of buildings (Basinger et al., 2010). In areas with dispersed housing and high costs of building classic water supply system, the RWHS (Rainwater Harvested System) was found to be an affordable and sustainable alternative (Khan et al., 2017, Kimani et al., 10 2015) of drinking water supply.

In households, rainwater can be used i.e. for sanitary facilities flushing, laundry, cleaning, watering lawns and crops as well as for washing cars. In areas particularly exposed at the risk of water deficit, rainwater is also taking into consideration as water intended for consumption, i.e. in Kenya and Bangladesh (Evans et al., 2006). Thus, the knowledge of the quality of harvested water is crucial for the protection of public health.

15 While it is generally believed that rainwater is relatively clean, the test results obtained prove it physical, chemical and microbiological pollution (Zdeb et al., 2016, Gwenzi et al., 2015). The quality of the harvested rainwater is characterized by a significant variability both in time and space. The composition of rainwater is dependent on many factors such as i.e.: atmospheric pollution (including the presence of dusts, pollen, bioaerosol), type of catchment, land use (industrial areas, roads and highways), local microclimate and the type of the run-off surfaces (various roof pitches and various roofing materials). In

20 urban areas, the rainwater contamination reaches highest levels, which is mainly linked to the emissions by power plants, local boiler plants and industry (Fiedler et al., 2017, Despins et al., 2009).

Water quality is a very important factor as regards possible options of utilization for economy, although not only highest quality water meeting the standards for consumption and hygienic applications is required for such utilization. Rainwater can be a carrier of surface water pollution and soil. Research on their quality may partly explain the impact of rainfall, for example

25 on the condition of water in water reservoirs (Koszelnik, 2007).

The aim of this article is to examine the physical, chemical and microbiological quality of rainwaters harvested in suburban areas and the assessment of utilization possibilities of this water for different economic purposes, including also potable water supplies in crisis conditions.

\section{Location of the study area}

30 The research was carried out in 2015-2016 on a non-industrialized area located in the immediate vicinity of the city of Rzeszów, which is located in the south-eastern part of Poland (Fig. 1). 
Hydrol. Earth Syst. Sci. Discuss., https://doi.org/10.5194/hess-2019-117

Manuscript under review for journal Hydrol. Earth Syst. Sci.

Discussion started: 29 April 2019

(c) Author(s) 2019. CC BY 4.0 License.

(c) $\underset{\mathrm{BY}}{(i)}$

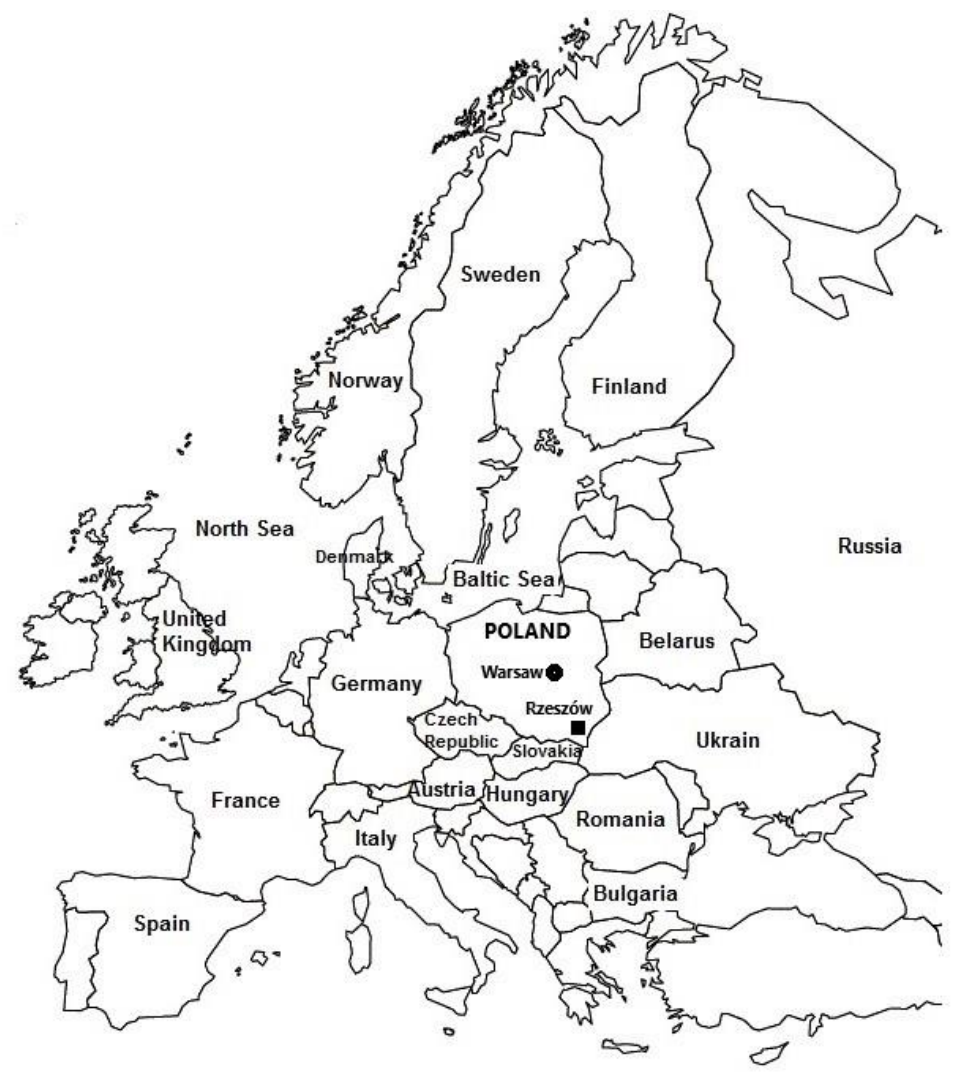

Fig. 1. Location of Rzeszów against the background of Europe

The area within a radius of $3 \mathrm{~km}$ from the sampling site is characterized by low emission of dust pollution due to the lack of industrial and organic plants, excluding the summer period, when their formation is associated with mowing grass. The nearest transport route is a county road with a limited traffic intensity (LR), $0.3 \mathrm{~km}$ away from the sampling site, and a national road (NR), $5.5 \mathrm{~km}$ away southerly direction. The area where sampling was conducted, where overgrown with low shrubs and grasses, and the nearest trees and agricultural fields were located approximately $1 \mathrm{~km}$ to the west of the housings. To the north-west of the sampling site, there is a water treatment plant $(2.5 \mathrm{~km})$ and the CHP plant Załęże (approx. $5 \mathrm{~km})$. Westerly and south-westerly winds prevailed (Fig. 2). 
Hydrol. Earth Syst. Sci. Discuss., https://doi.org/10.5194/hess-2019-117

Manuscript under review for journal Hydrol. Earth Syst. Sci.

Discussion started: 29 April 2019

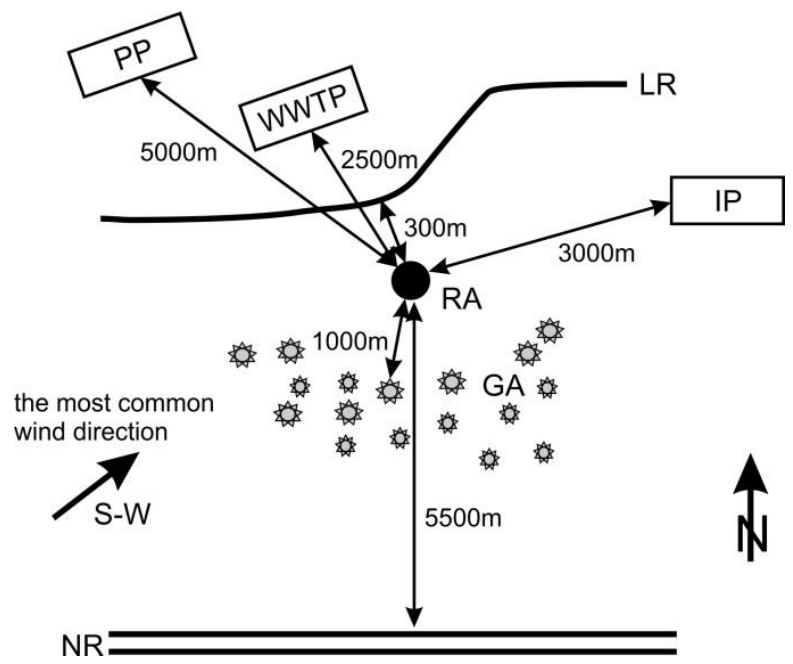

Fig. 2. Characteristics of the research area

\section{Research methodology}

Water samples were collected in the following seasons: spring (March-May), summer (June-August) and autumn (September-

5 November), excluding winter, when temperatures below $0{ }^{\circ} \mathrm{C}$ and there are no technical opportunities for rainwater. Rainwater quality tests were carried out for samples taken from outlet pipes that lead them out of the roofs. The impact of roofing materials on water quality was analyzed. The following materials were analyzed in the study: I) concrete roof tiles (Co), II) ceramic roof tiles (Ce), III) zinc coated metal sheets (Gs) and IV) epoxide coated (E). The control was a rainwater sample which did not come into contact with any roof surface and was collected directly from atmospheric precipitation (P).

10 Samples were collected during selected rain episodes according to rain fall intensity and after rejecting the so called first runoff. The first run-off time was established for intensive and moderate rain falls and for heavy or moderate torrential rain. A determining factor was the possibility to measure rain fall intensity with available tools. Sampling was carried out at particular points of time after the start of the rainfall and quality control marks were made (Table 1.).

15 Table 1. Changes in the quality of rainwater during precipitation - determining the time of the first runoff.

\begin{tabular}{|c|c|c|c|c|c|c|}
\hline \multirow{3}{*}{$\begin{array}{c}\text { Duration } \\
\text { of rain } \\
\text { [min] }\end{array}$} & \multicolumn{4}{|c|}{$\begin{array}{c}\text { Number of bacteria } \\
{[\mathrm{cfu} / \mathrm{ml}]}\end{array}$} & \multirow{2}{*}{\multicolumn{2}{|c|}{$\begin{array}{l}\text { Turbidity } \\
\text { [NTU] }\end{array}$}} \\
\hline & \multicolumn{2}{|c|}{ mesophilic } & \multicolumn{2}{|c|}{ psychrofile } & & \\
\hline & $\begin{array}{l}\text { rainwater } \\
\text { directly from } \\
\text { atmospheric } \\
\text { precipitation }\end{array}$ & $\begin{array}{l}\text { rainwater } \\
\text { from a roof } \\
\text { covered with } \\
\text { concrete tiles }\end{array}$ & $\begin{array}{l}\text { rainwater } \\
\text { directly from } \\
\text { atmospheric } \\
\text { precipitation }\end{array}$ & $\begin{array}{l}\text { rainwater } \\
\text { from a roof } \\
\text { covered with } \\
\text { concrete tiles }\end{array}$ & $\begin{array}{l}\text { rainwater } \\
\text { directly from } \\
\text { atmospheric } \\
\text { precipitation }\end{array}$ & $\begin{array}{l}\text { rainwater } \\
\text { from a roof } \\
\text { covered with } \\
\text { concrete tiles }\end{array}$ \\
\hline 1 & 105 & 101 & 1206 & 1600 & 7 & $>10$ \\
\hline 2 & 89 & 50 & 997 & 1267 & 4 & 5 \\
\hline
\end{tabular}


Hydrol. Earth Syst. Sci. Discuss., https://doi.org/10.5194/hess-2019-117

Manuscript under review for journal Hydrol. Earth Syst. Sci.

Discussion started: 29 April 2019

(c) Author(s) 2019. CC BY 4.0 License.

(c) (i)
Hydrology and

Earth System

Sciences

Discussions

\begin{tabular}{|l|l|l|l|l|l|l|}
3 & 75 & 55 & 512 & 1210 & 4 & 3 \\
4 & 10 & 78 & 610 & 1300 & 5 & 3 \\
5 & 69 & 26 & 486 & 1200 & 4 & 2 \\
10 & 55 & 20 & 212 & 840 & 3 & 2 \\
20 & 60 & 25 & 155 & 613 & 3 & 2 \\
30 & 80 & 30 & 178 & 500 & 3 & 2 \\
\hline
\end{tabular}

On this basis, the time necessary for the first run-off of roof surfaces and the moment for sampling during rainfall were set. The measurement was made for rainwater collected directly from atmospheric precipitation and from a concrete tile roofing. Basing on the results obtained, it had been established, that samples would be taken as of the 10th minute of rain with a defined

5 intensity.

The selected physical, chemical and microbiological rainwater parameters were determined according to applicable surface water and groundwater research procedures and standards (Table 2.).

Table 2. Scope and methodology for the determination of physicochemical and microbiological properties for the examined 10 rainwater.

\begin{tabular}{|c|c|}
\hline Parameter & Method /standard \\
\hline $\mathrm{pH}$ & Electrometric method; EN ISO 10523: 2012 \\
\hline Conductivity & Electrometric method; EN 27888: 1999 \\
\hline turbidity & Nephelometric method; EN ISO 7027: 2003 \\
\hline $\begin{array}{l}\text { ammonium ion, nitrite nitrogen, nitrate } \\
\text { nitrogen, phosphates }\end{array}$ & Ion chromatography method, EN ISO 10304-1: 2009 \\
\hline General Organic Carbon (OWO) & analyzer TOC Sievers 5310 C; EN 1484: 1999 \\
\hline $\begin{array}{l}\text { heavy metals: copper, lead, chromium, } \\
\text { nickel, zinc; trace elements: arsenic, } \\
\text { titanium, bromine, strontium }\end{array}$ & $\mathrm{X}$-ray spectrometry method; procedures for equipment PICOFOX \\
\hline the number of Escherichia coli bacteria & The membrane filter method; EN ISO 9308-1:2004 \\
\hline the number of fecal streptococci & The membrane filter method; EN ISO 7889-2:2004 \\
\hline
\end{tabular}

\section{Results and discussion}

\subsection{Test cycles characteristics}

Test were carried out for rainwater harvested in the years 2015 and 2016. Each test cycle was described with the number of

15 rain episodes, total monthly rainfall, duration of intervals between rainfalls and average air temperatures (Table 3.).

Table 3. Characteristics of research cycles 
Hydrol. Earth Syst. Sci. Discuss., https://doi.org/10.5194/hess-2019-117

Manuscript under review for journal Hydrol. Earth Syst. Sci.

Discussion started: 29 April 2019

\begin{tabular}{|l|c|c|}
\hline \multicolumn{1}{|c|}{ Characteristic } & year 2015 & year 2016 \\
\hline Number of rain events & 31 & 48 \\
The number of rain events analyzed & 11 & 23 \\
Total precipitation from research months $[\mathrm{mm}]$ & 254 & 413 \\
Average air temperature in spring $\left[{ }^{\circ} \mathrm{C}\right]$ & 12,3 & 12,2 \\
Average air temperature in the summer $\left[{ }^{\circ} \mathrm{C}\right]$ & 24 & 19,5 \\
Average air temperature in autumn $\left[{ }^{\circ} \mathrm{C}\right]$ & 10,5 & 15,1 \\
The longest break between precipitation [days] & 40 & 27 \\
Months with rainfall over 40mm & III & IV, V, VII, IX, XI \\
\hline
\end{tabular}

In 2015, there was a significantly smaller number of rain events, longer rainless periods and higher air temperatures than in 2016.

Annually rainfall in 2016 was nearly twice as high as in 2015. The characteristics of test seasons refer to the area where

5 rainwater samples were taken. In 2016, a monthly precipitation exceeding $40 \mathrm{~mm}$ was recorded in April, May, July, September, October and November, while in 2015 only in March.

\subsection{Physical and chemical rainwater quality}

Parameters most commonly used for the description of rainwater quality are the $\mathrm{pH}$ and turbidity. The lowest $\mathrm{pH}$ values were recorded for rainwater collected directly from atmospheric precipitations (Fig. 1). 
Hydrol. Earth Syst. Sci. Discuss., https://doi.org/10.5194/hess-2019-117

Manuscript under review for journal Hydrol. Earth Syst. Sci.

Discussion started: 29 April 2019

(c) Author(s) 2019. CC BY 4.0 License.

\section{(c) (1)}

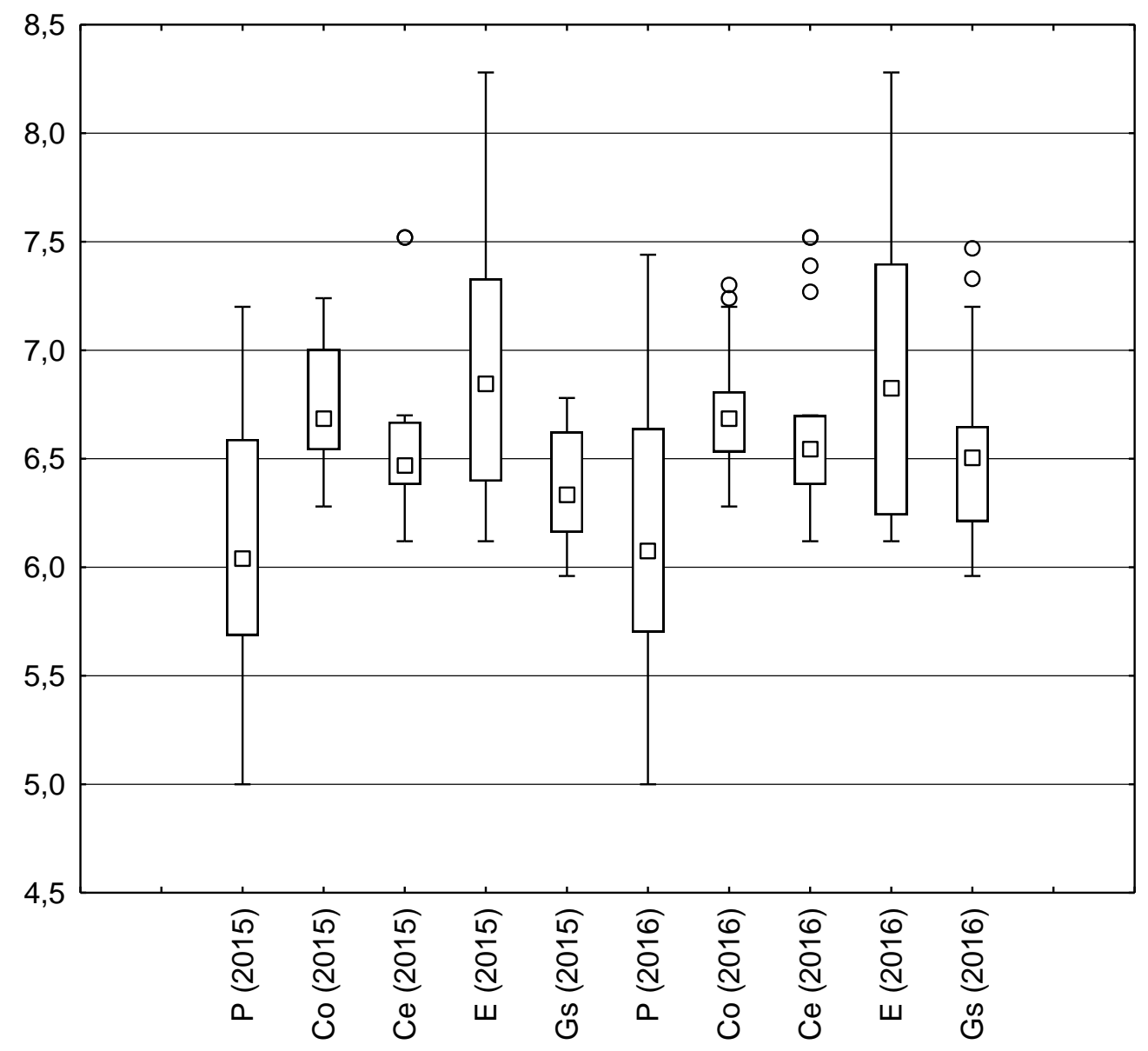

$\square$ median

$\square 25 \%-75 \%$

I non-outliers

o outliers

* extremly outliers

Figure 3. $\mathrm{pH}$ of the tested rain water

Among rainwaters collected from different roofing materials the lowest $\mathrm{pH}$ was noted for rainwater collected from a zinc coated metal sheet.

5 In rainwater collected directly from atmospheric precipitations lower $\mathrm{pH}$ values were noted than in the roof-harvested rainwater. Rain water deposited due to the air pollution - sulfur compounds and $\mathrm{NO}_{\mathrm{x}}$ had acidic character. However, in a further step after the trailing surfaces of the roof, degree of neutralization gradually changes. Rain water deposited due to the air pollution - sulfur compounds and $\mathrm{NO}_{\mathrm{x}}$ had acidic character.

In turn, characterized by the highest turbidity water collected from the surface coated with epoxy resin - max. 14 NTU, and the lowest turbidity was found in rainwater collected from the zinc coated metal sheet - medians 1.5 and 2.0 NTU (Fig. 4). 
Hydrol. Earth Syst. Sci. Discuss., https://doi.org/10.5194/hess-2019-117

Manuscript under review for journal Hydrol. Earth Syst. Sci.

Discussion started: 29 April 2019

(c) Author(s) 2019. CC BY 4.0 License.

\section{(c) (i)}

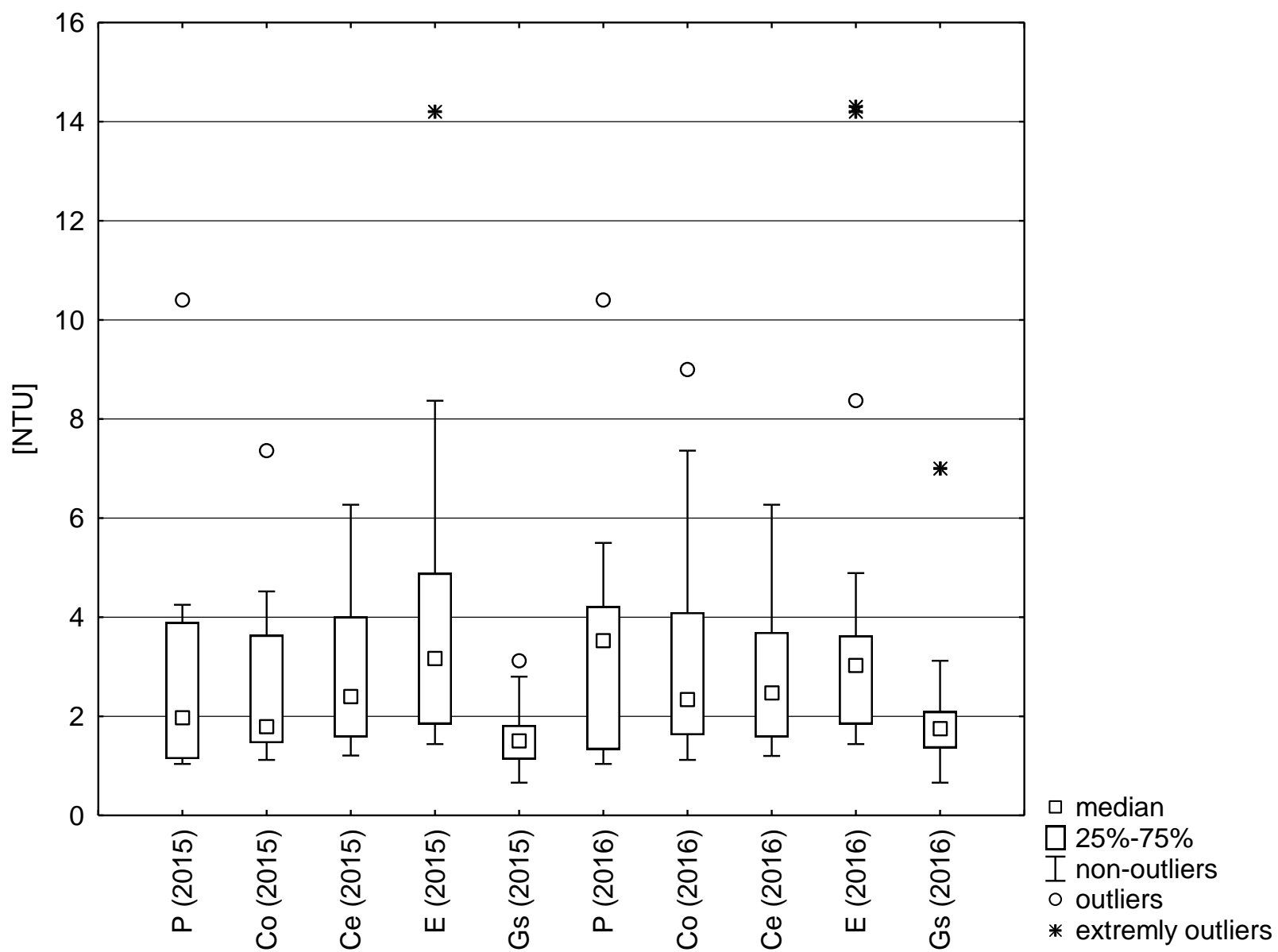

Figure 4. Turbidity of rainwater tested

In the case of water harvested directly from air, the turbidity reached 4 NTU in 2015 and 2 NTU in 2016.

The amounts of nitrogen compounds for all examined rainwater samples were at a similar level (Fig. 5.)
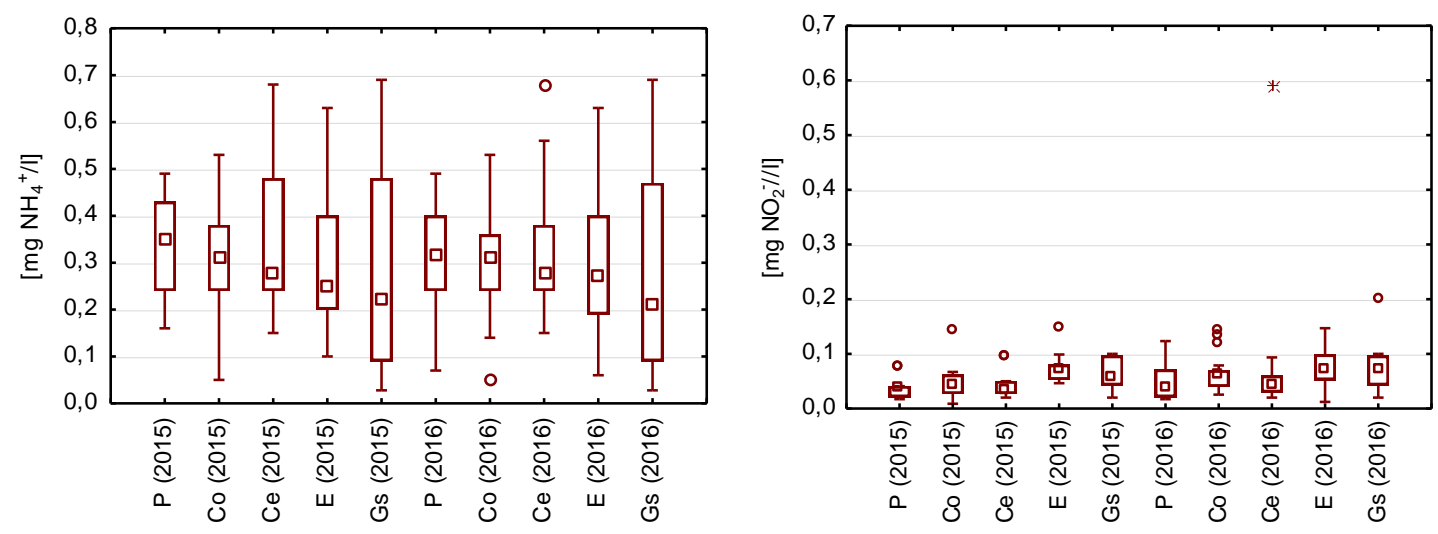
Hydrol. Earth Syst. Sci. Discuss., https://doi.org/10.5194/hess-2019-117

Manuscript under review for journal Hydrol. Earth Syst. Sci.

Discussion started: 29 April 2019

(c) Author(s) 2019. CC BY 4.0 License.

\section{(c) (1)}

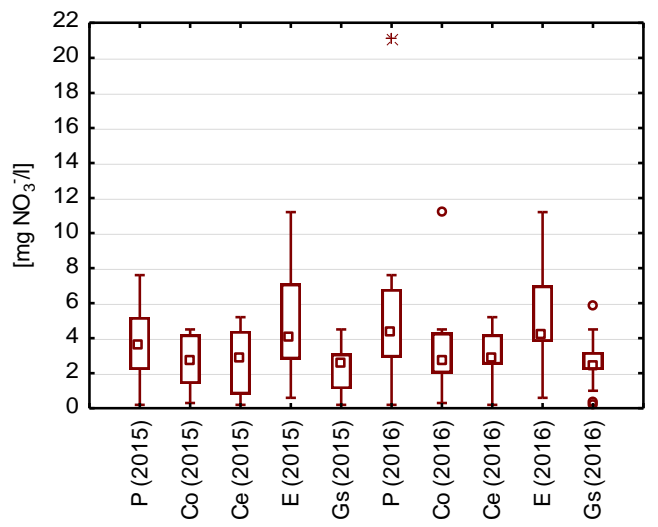

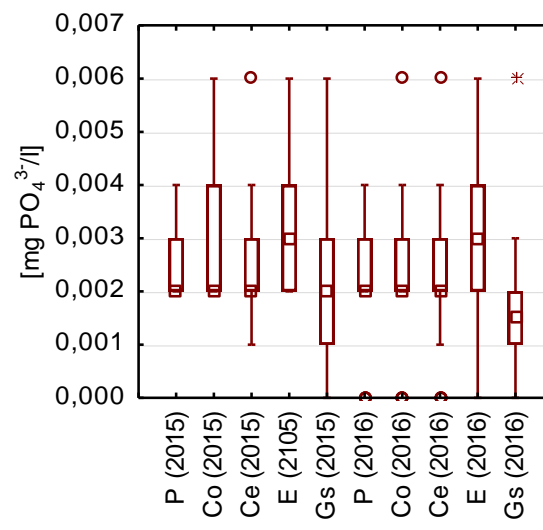

Hydrology and

Figure 5. Statistical data for the content of nutrients in the analyzed rainwater

Middle values of ammoniacal nitrogen concentrations were found to be in the range $0,20-0,35 \mathrm{mg} \mathrm{NH}_{4}^{+} / 1$. Extreme values obtained for rainwater collected from galvanized steel and the rainwater collected directly from precipitation.

5 The highest concentrations of nitrite (III) were determined in rainwater taken from the surface covered with epoxy resin and amounted to $4 \mathrm{mgNO}_{2} / \mathrm{l}$, and the lowest in rainwater flowing from the washing ceramic, concrete and galvanized sheet, for which it reached the value of $2 \mathrm{mgNO}_{2} / 1$.

The lowest amounts of phosphates were found in rainwater collected from zinc coated metal sheet, and the highest in rainwater from the surface covered with epoxide coated.

10 Total organic carbon (TOC) is a parameter describing the level of water pollution by organic matter. The highest middle TOC values were identified for the rainwater from the surface covered with epoxide coated $-5 \mathrm{mg} \mathrm{C} / \mathrm{l}$ (Fig. 6.). 
Hydrol. Earth Syst. Sci. Discuss., https://doi.org/10.5194/hess-2019-117

Manuscript under review for journal Hydrol. Earth Syst. Sci.

Discussion started: 29 April 2019

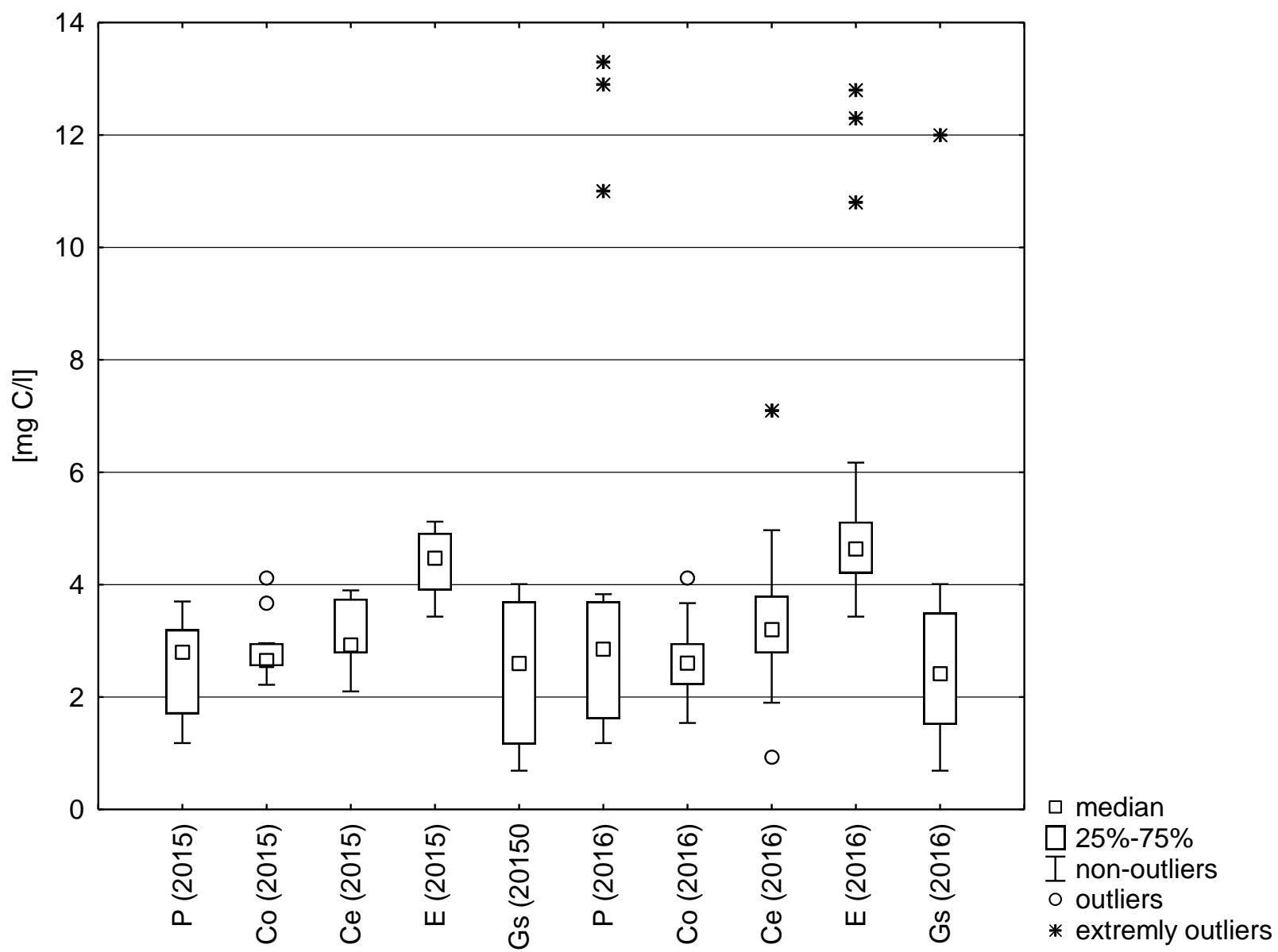

Fig. 6. Statistical data for total organic carbon content in the analyzed rain water

\subsection{Heavy metals in rainwater}

The results of the analysis focussing on heavy metal ions in both test cycles are displayed in Fig. 5 and 6. Each tested water

5 sample appeared to contain trace amounts of nickel, chromium, lead and arsenic at concentrations slightly above $1 \mu \mathrm{g} / \mathrm{l}$, ions of copper, manganese, bromine and strontium at levels around $10 \mu \mathrm{g} / 1$ and of iron, zinc, titanium and silver in amounts often exceeding $100 \mu \mathrm{g} / \mathrm{l}$.

Electrical conductivity of rainwater collected from different roofing and directly from the air fluctuated between 1 and 26 $\mu \mathrm{S} / \mathrm{cm}$, and the middle values were from 1 to $4 \mu \mathrm{S} / \mathrm{cm}$ (Fig. 7 and 8.). 
Hydrol. Earth Syst. Sci. Discuss., https://doi.org/10.5194/hess-2019-117

Manuscript under review for journal Hydrol. Earth Syst. Sci.

Discussion started: 29 April 2019

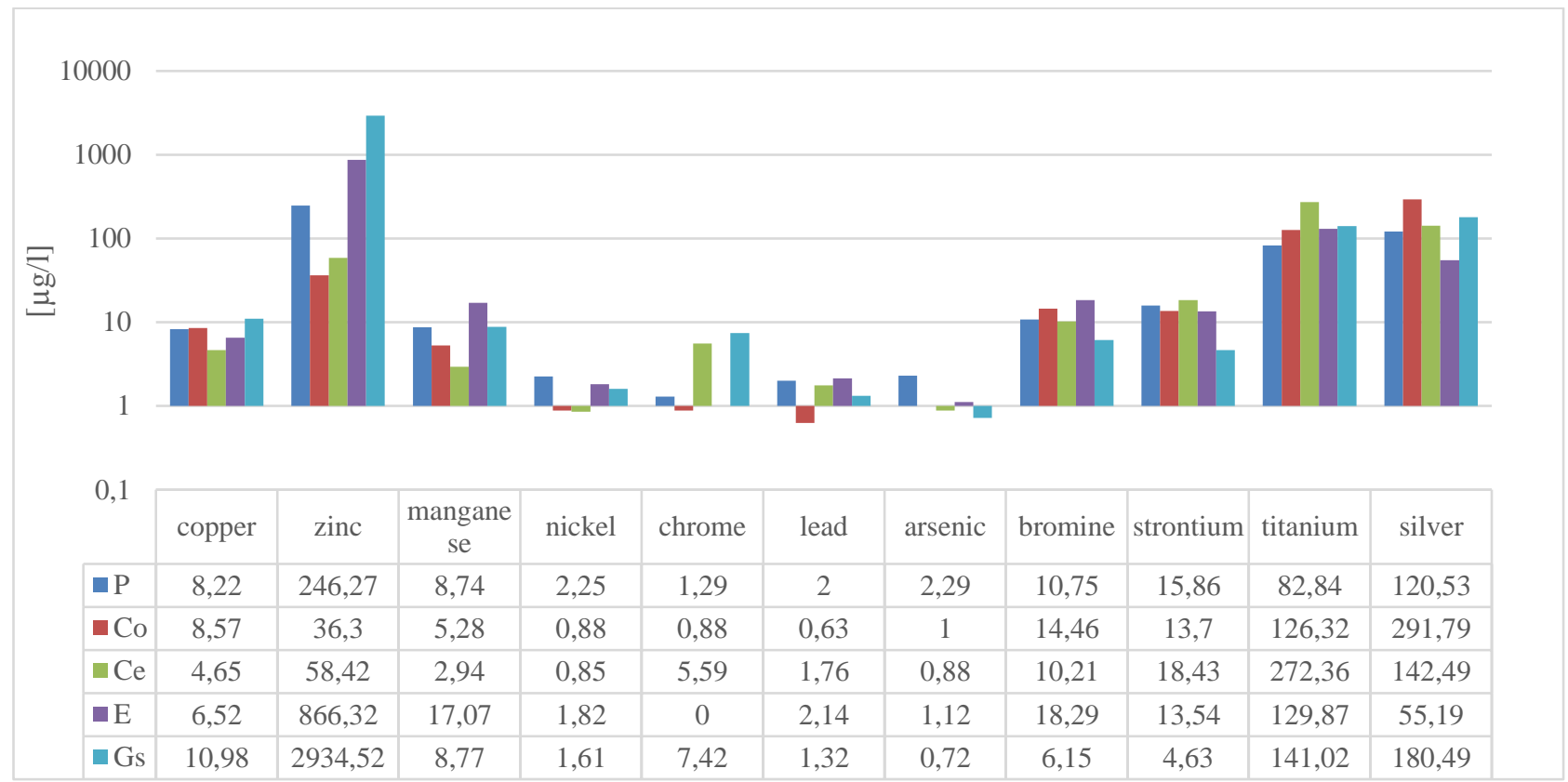

Fig. 7. Median concentration of ions in rainwater in 2015

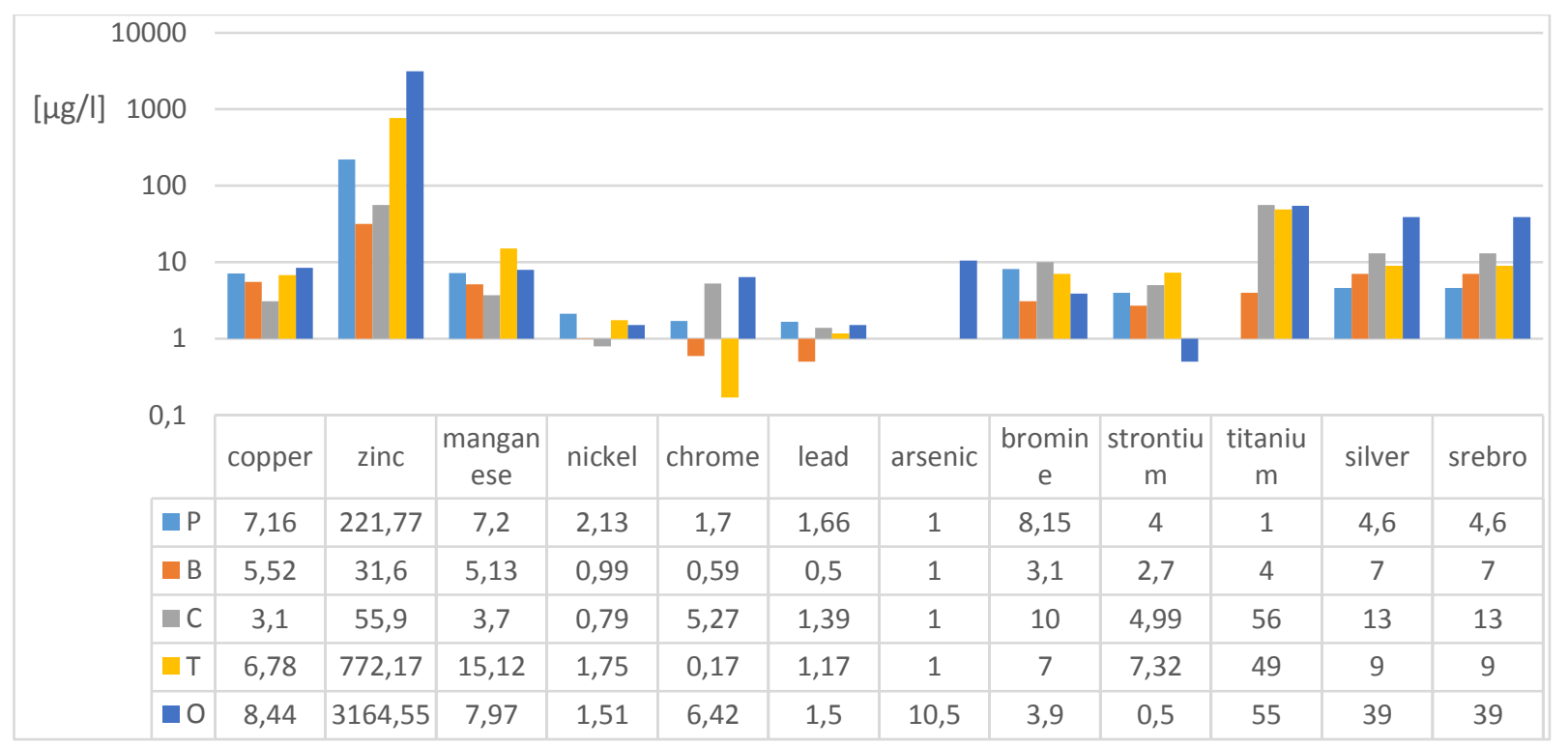

Fig. 8. Median concentration of ions in rainwater in 2016

5 The lowest electrical conductivity values were recorded for water collected from the guttering of a roof covered with zinc coated metal sheets (like in the control sample collected directly from atmospheric precipitations). It was not clearly indicated, for which type of rainwater this parameter had highest values. 
Hydrol. Earth Syst. Sci. Discuss., https://doi.org/10.5194/hess-2019-117

Manuscript under review for journal Hydrol. Earth Syst. Sci.

Discussion started: 29 April 2019

(c) Author(s) 2019. CC BY 4.0 License.

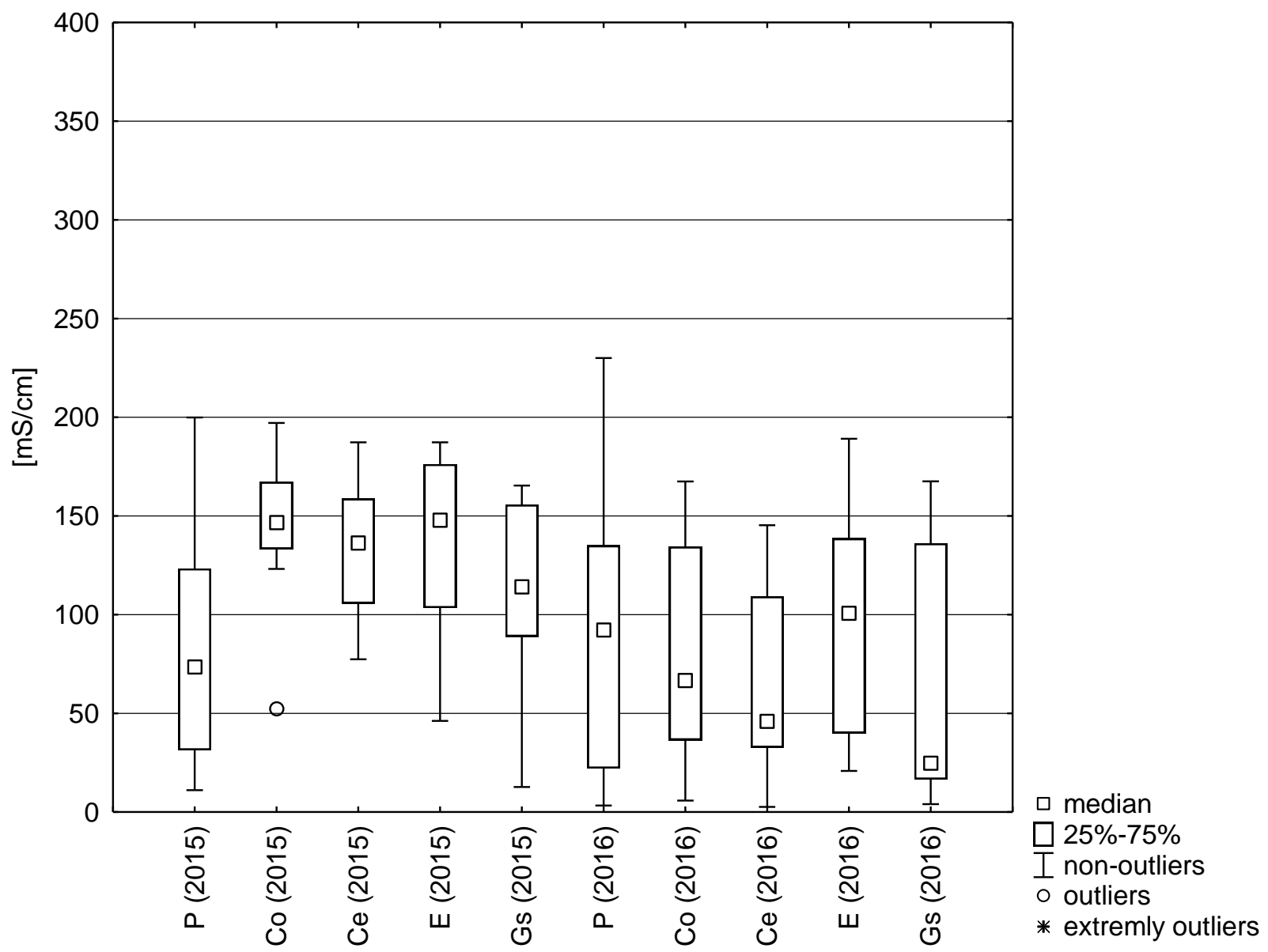

Figure 9. Statistical data for the specific conductivity in the analysed rainwater

\subsection{Microbiological quality of rainwater}

Sanitary quality aspects of water are normally defined by two factors - the number of Escherichia coli and the number of

5 faecal enterococci.

E. coli bacteria were found in each rainwater tested (Fig. 10.). 
Hydrol. Earth Syst. Sci. Discuss., https://doi.org/10.5194/hess-2019-117

Manuscript under review for journal Hydrol. Earth Syst. Sci.

Discussion started: 29 April 2019

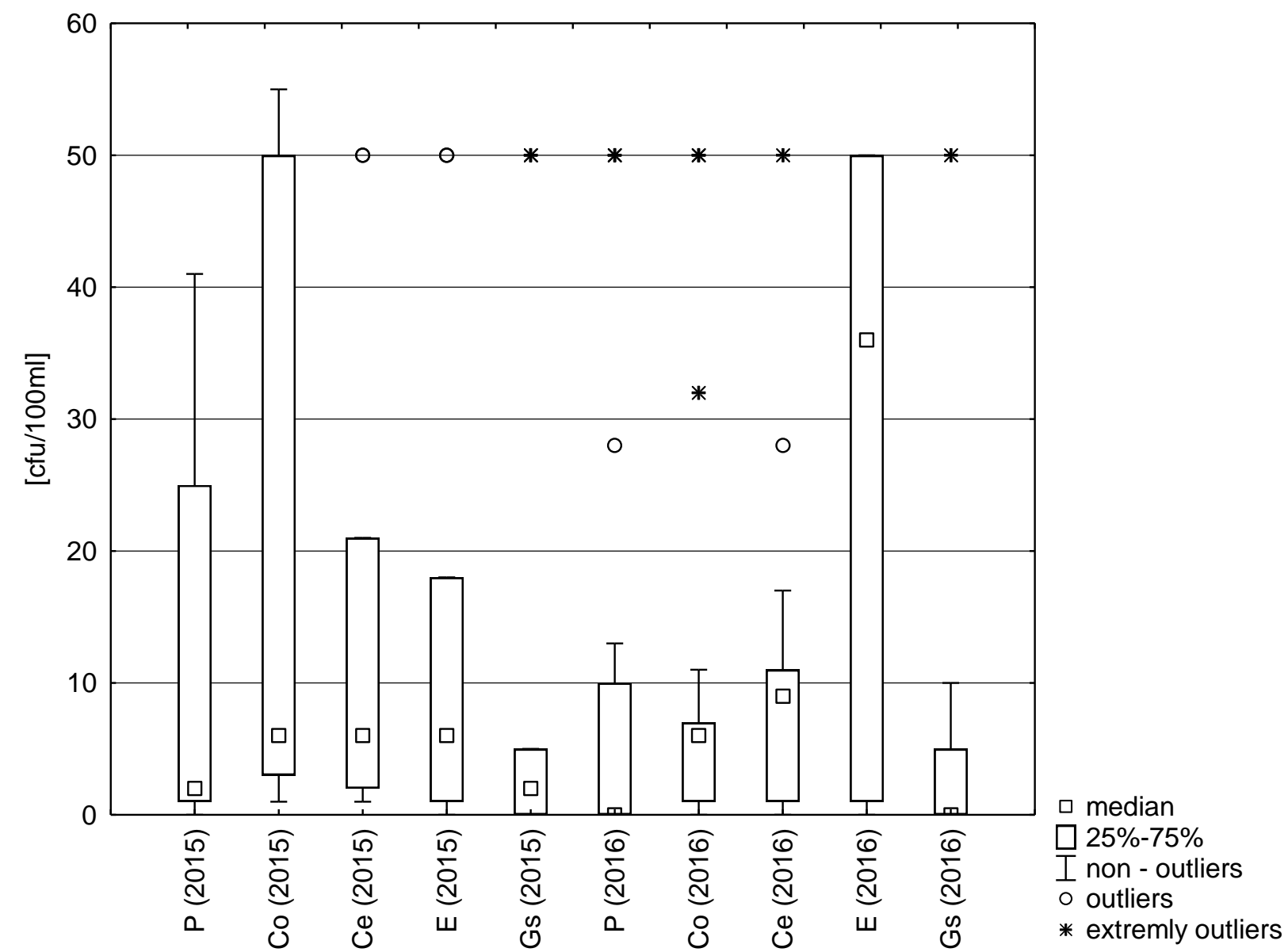

Figure 10. Statistical data for the number of Escherichia coli bacteria present in rainwater

E. coli were most numerous in rainwater collected from concrete tile roofing for the test seasons from 2015 and in terracecollected rainwater in 2016. The lowest number of E. coli

(excluding the lowest and highest outliers) were marked for the rainwater collected from zinc coated metal sheet roofing - less than $5 \mathrm{cfu} / 100 \mathrm{ml}$. In this rainwater, the number of bacteria was similar in both test cycles. However, the number of faecal streptococci in rainwater collected directly from atmospheric precipitations and from concrete and ceramic tile roofs and zinc coated metal sheet roof was lower in 2016 than in 2015. The values were similar in both test cycles only for the rainwater from the epoxide covered surface (Fig. 11.). 
Hydrol. Earth Syst. Sci. Discuss., https://doi.org/10.5194/hess-2019-117

Manuscript under review for journal Hydrol. Earth Syst. Sci.

Discussion started: 29 April 2019

(c) Author(s) 2019. CC BY 4.0 License.

(c) (i)
Hydrology and

Earth System

Sciences

Discussions

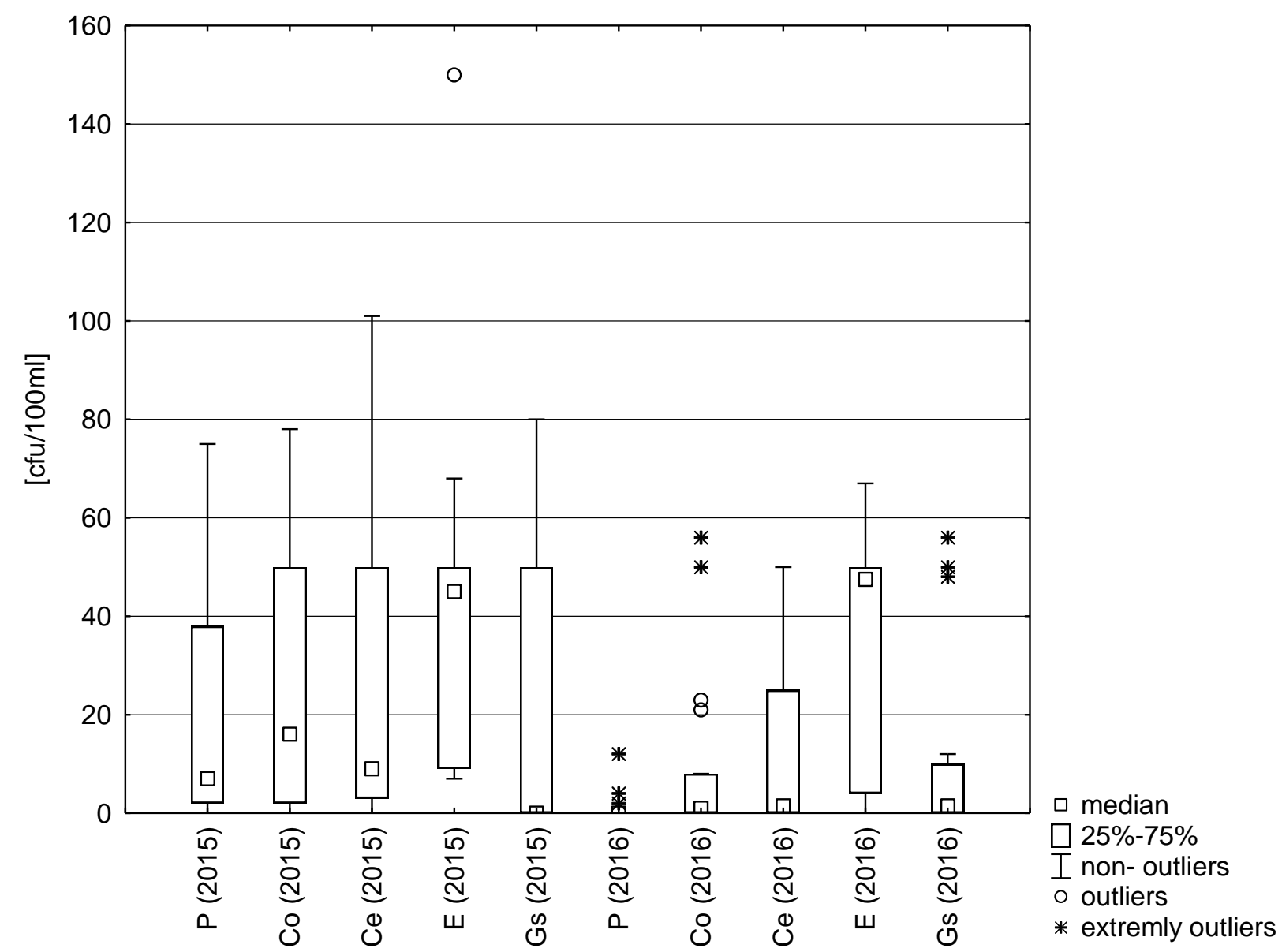

Figure 11. Statistical data for the number of Enterococci present in rainwater

The highest median values of faecal streptococci were established for rainwater collected from the surface covered with epoxide coated terrace - approx. $50 \mathrm{cfu} / 100 \mathrm{ml}$.

\section{4. Discussion}

All results obtained describing the quality of rainwater collected from both roof surfaces and directly from atmospheric precipitation took into account the so-called time of the first runoff. Literature data indicate differences in the quality of rainwater collected from the beginning of the rainfall and the one after the designated time of the first runoff. Nosrati shows even four times higher concentrations of phosphates, sulphates and nitrates in waters collected from bituminous roof without taking into account the first runoff in relation to the water collected after a certain time from the beginning of the fall (Nosari, 2017). 
Hydrol. Earth Syst. Sci. Discuss., https://doi.org/10.5194/hess-2019-117

Manuscript under review for journal Hydrol. Earth Syst. Sci.

Discussion started: 29 April 2019

Hydrology and

Earth System

(c) Author(s) 2019. CC BY 4.0 License.

Sciences

Discussions

(c) ${ }_{\mathrm{Br}}$

The presented rainwater turbidity tests prove that this parameter is dependent on the roughness of the roof covering material. The rainwater turbidity increases with the roughness of the roof surface. Leong et al. demonstrate reverse dependencies, indicating the rainwater dirt holding capacity in rough surfaces. For glass, metal and ceramic surfaces the following maximum turbidity values were established: 92.9 NTU, 57.1 NTU, 10.1 NTU (Leong et al., 2017). Naddeo et al. report significantly

5 higher turbidity values for rainwater collected directly from air: 25.88 NTU in comparison to the obtained result of 4 NTU. This may result from a higher number of suspended dust particles as well as from the fact that the tests were conducted in an urban area (Naddeo et al., 2011). Rainwater turbidity can be also a result of revivable bacteria (Ding et al., 2017).

The determination of the concentration of nitrogen compounds proves to be particularly important with regard to microbiological tests and the assessment of the conditions of survival and growth of bacteria in water. The source of nutrients

10 in rainwater from atmospheric precipitations can be plants pollens, fungal spores, bacterial cells and spores as well as other substances from i.e. agricultural crops, which pollute roof surfaces by dry deposition. In addition, nutrients may also come from natural sources such as bird droppings, bryophytes and lichens polluting roof run-offs (Ducan et al., 1995). In the analyzed rainwater, regardless of the type of roofing material, the value of nitrogen compounds oscillated around the value of $0.2-0.4$ $\mathrm{mg} \mathrm{NH}_{4}+/$ l. Research on the content of nitrogen compounds in rainwater in urbanized areas showed significantly lower

15 concentrations of NH4 + ions and amounted to an average of $0.02 \mathrm{mg} / \mathrm{dm} 3$ (Lee et al., 2011).

The highest nitrate concentrations were recorded for rainwater collected from concrete and ceramic tiles roofing. Similar nitrate concentrations to those determined for rainwater collected from concrete tiles roofing were found in strongly urbanized areas (Lee et al., 2012).

In turn, the concentration of phosphates in the analyzed rainwater samples oscillated around the value of $0.02 \mathrm{mg} \mathrm{PO}_{4}{ }^{3-} / 1$.

20 Duncan et al. (1995) in his research observed in the rainwater from the urban zone concentration of $0.01-0.10$ mg $\mathrm{PO}_{4}{ }^{3-} / 1$. Other authors emphasize the significant impact of surface roughness on the content of biogenic substances including (Lai et al., 2018). This observation coincides with the obtained test results. The differences in levels of phosphates and nitrogen compounds that occurred between water samples collected from different roof may be primarily due to the structure of these surfaces and the possibility of washing out dry deposition pollutants.

25 It should also be noted that the inclination of the roof surface can have a significant impact on the quality of rainwater. The conducted research indicates that the values of turbidity, nitrates, phosphates or TOC are the highest in rainwater harvested from the roof with a minimum inclination angle (covered with epoxy resin). This is confirmed by studies carried out much earlier on the quality of rainwater collected, among others from roofs covered with shingles, green roofs and so-called cold roofs with smooth coatings to prevent overheating. The results for parameters such as turbidity or total organic carbon content

30 were almost twice as high in waters collected from smooth roof surfaces with a small inclination angle compared to waters collected from roofs with rough surfaces with a higher slope angle (Mendez, 2011).

In the research cycle carried out in 2016, the concentrations of elements detected in the water collected directly from air as well as from different roof surfaces, occurred to be lower than in the test cycle 2015. This may result from a higher total rainfall in 2016. As it results from the analyzes of literature The presence of heavy metals was recorded in virtually all types rainwater: 
Hydrol. Earth Syst. Sci. Discuss., https://doi.org/10.5194/hess-2019-117

Manuscript under review for journal Hydrol. Earth Syst. Sci.

Discussion started: 29 April 2019

from natural (Türküm et al., 2008), strongly urbanized (Bai et al., 2014; Xu et al., 2015), and rural areas (Gikas et al., 2012), in both stored rainwater (Despins et al., 2009) and the so called first run-off (Lee et al., 2012; Georgios et al., 2012). The source of heavy metals present in rainwater are the surfaces washed by rainwater, where these pollutants accumulate by dry deposition. The solubility of non-ferrous metals, such as i.e. lead, may vary according to the rainwater pH (Chester et al., 1997). Metals

5 such as $\mathrm{Cd}, \mathrm{V}, \mathrm{Cu}$ and $\mathrm{Zn}$ demonstrate a higher solubility than $\mathrm{Ni}, \mathrm{Cr}$ and $\mathrm{Pb}$, both in wet and dry deposits (Morselli et al., 2003; Gunawardena et al., 2013). This is confirmed by the concentrations achieved by these elements in the analysed rainwater types.

Water collected from a roof covered with zinc coated metal sheets is distinguished by higher zinc content (3164,55 $\mu \mathrm{g} \mathrm{Zn} / \mathrm{l})$ than other samples (less than $1000 \mu \mathrm{g} \mathrm{Zn/l).} \mathrm{This} \mathrm{dependency} \mathrm{on} \mathrm{roofing} \mathrm{material} \mathrm{was} \mathrm{also} \mathrm{found} \mathrm{by} \mathrm{other} \mathrm{researchers} \mathrm{(Lee} \mathrm{et}$

10 al., 2010; Mendez et al., 2011; Yaziz et al., 1989; Vialle et al., 2011).

Electrical conductivity is an indicator of any positive or negative ions present in the water. It may indicate pollution by i.e. heavy metal ions. In the analysed waters, the electrical conductivity was around $1-4 \mu \mathrm{S} / \mathrm{cm}$ (median). Zhang et al. obtained similar results for waters collected from roofs covered with roof tiles and sheets, and a significantly higher conductivity was determined for run offs from the so-called green roof (Zhang et al., 2014). The general mineralization of rainwaters in natural

15 conditions may be only several milligrams of the substance dissolved per litre of water, however, in industrialized regions, the mineralization level is increased. The values obtained are relatively low in comparison to those recorded in industrialized zones $-614,8 \mu \mathrm{S} / \mathrm{cm}$ (Bai et al., 2014).

In each rainwater type test, including the rainwater collected directly from atmospheric precipitations, indicative bacteria levels from faecal contamination were detected. The presence of such bacteria was demonstrated by almost all analogue studies. Lee

20 et al. determined a lower amount of E. coli in rainwater collected from concrete tiles roof $(2 \mathrm{cfu} / 100 \mathrm{ml}), \mathrm{ceramic}(1 \mathrm{cfu} / 100$ $\mathrm{ml})$ and zinc coated metal sheets $(0 \mathrm{cfu} / 100 \mathrm{ml})$. It is interesting to note, that in extensive green roof water leachate an average amount of only $1 \mathrm{cfu} / 100 \mathrm{ml}$ was identified. It is believed that the substrate for plant growth may create, in a certain sense, deposit and conditions for the creation of biofilm, which makes washing out microorganisms from roof surfaces more difficult (Lee et al., 2012).

25 In rainwater samples collected without rejecting the so-called first run-off, the number of E. coli can be significantly higher $5500 \mathrm{cfu} / 100 \mathrm{ml}$ (Dobrowolsky et al., 2014), and even $7670 \mathrm{cfu} / 100 \mathrm{ml}$ (Leong et al., 2017). This is also confirmed by the research mentioned previously done by Lee et al., where the bacteria numbers from the first run-off in waters collected from different surfaces were as follows: concrete roof tiles $-18 \mathrm{cfu} / 100 \mathrm{ml}$, ceramic roof tiles $-8 \mathrm{cfu} / 100 \mathrm{ml}$, zinc coated metal sheets $-4 \mathrm{cfu} / 100 \mathrm{ml}$ (Lee et al., 2012).

30 Escherichia coli, faecal streptococci are almost always detected in roof-harvested rainwater. Comparing the middle values of enterococci, it can be noted that their numbers were lower in 2016 than in 2015 . The reason may be the number of rain episodes in individual research cycles, and thus the frequency of leaching microbiological pollutants from roof surfaces. Only for a roof with a minimum inclination, the results were comparable in both research cycles. 
Hydrol. Earth Syst. Sci. Discuss., https://doi.org/10.5194/hess-2019-117

Manuscript under review for journal Hydrol. Earth Syst. Sci.

Discussion started: 29 April 2019

E. coli and faecal streptococci are micro-organisms present at high levels in faeces of both humans and animals. The presence of these bacteria in roof-harvested rainwater can be explained by the deposition of faeces on these roofs by birds and small mammals (Śmigielska, 2010). A potential source of contamination by faecal micro-organisms can be also soil particles carried by wind from agricultural fields fertilized with organic substances or the bio-aerosols from free-standing, unsheltered reactors

5 of biological wastewater treatment plants - especially because sampling points of tested waters are located south from the above-mentioned potential sources of micro-organisms, while south-west winds were predominant. Some studies which appear to confirm this hypothesis show that bacteria contained in droplets of water carried by wind can travel even up to $1 \mathrm{~km}$ retaining their viability (Korzeniewska et al., 2008, Ekstrom S. et al., 2010, Ahern et al., 2007, Cho and Chwang, 2011, Polymenakou 2012).

10 Among the examined waters, the best microbiological quality was characterized by the one taken from the roof covered with galvanized sheet. This is related to the biocidal properties of zinc and the relatively smooth surface of the sheet. Mendez et al. indicate that adequate roofing can be an effective measure to prevent the growth of microorganisms. In the experimental studies, various roof coverings were used, and galvanized steel proved to be the cover with the greatest disinfection properties. This may have resulted from an increase in temperature on the roof surface (Mendez et al., 2011). The relationship between

15 the roughness of the roof material and the amount of microorganisms was confirmed by the majority of rainwater researchers (Leong et al., 2017, Dobrowsky et al., 2014).

At the same time, it is noted that depending on rainfall frequency and roofing material, the quality of roof-harvested rainwater can deteriorate or improve as compared to rainwater collected directly from atmospheric precipitations. This means that these waters cannot be used as a source of drinking water or for hygienic purposes, without prior treatment, which in certain

20 situations can be expensive and requires advanced processes.

The presence of indicative faecal bacteria contamination precludes this water being considered as safe for watering crops the fruit of which can be consumed without being cleaned (such as strawberries or raspberries). A safe utilization of this water can be only for laundry or dishwashing, provided that appropriate temperature is applied (above $60{ }^{\circ} \mathrm{C}$ ), as well as for typical cleaning activities in households such as washing driveways, car washing or lawn watering.

\section{5. Conclusions}

Comprehensive studies on the quality of rainwater discharged from roofs made of various materials allowed for the formulation of a number of general and specific applications.

- The quality of rainwater significantly depends on the material from which the roof surface is made. Rainwater collected from a roof covered with zinc coated metal sheets displayed the lowest $\mathrm{pH}$ (approx. $\mathrm{pH}=6.0$ ) and the lowest turbidity as compared

30 to water collected from other roof surfaces included in the research (concrete roof tiles, ceramic roof tiles, epoxide coated). The most polluted were the water collected from the surface covered with epoxy resin, which confirms the fact that surfaces 
Hydrol. Earth Syst. Sci. Discuss., https://doi.org/10.5194/hess-2019-117

Manuscript under review for journal Hydrol. Earth Syst. Sci.

Discussion started: 29 April 2019

with high roughness and a small angle of roof inclination tend to accumulate on their surface pollution, deteriorating the quality of rainwater. This is confirmed by the results of turbidity tests, biogenic substances or the number of bacteria.

- Observed that rough roofing materials provide favourable conditions for deposition of airborne pollutants which subsequently can be washed out by rainfalls. At the same time, it has been noted that in the event of less intensive precipitations microorganisms and chemical pollutants can be deposited in the pores of roofing materials, which results in a relatively good rainwater quality. This can be observed in waters collected from concrete and ceramic tile roofs - these water types show a better micro-biological, physical and chemical quality than the water collected directly from atmospheric precipitations.

- Smooth surfaces, eg sheet metal, very quickly rinse in the first moments of rainfall, both physicochemical and microbiological rainwater quality is very good. Smooth surfaces, eg sheet metal, very quickly rinse in the first moments of rainfall, both

10 physicochemical and microbiological rainwater quality is very good.

- In rainwater collected directly from atmospheric precipitations lower $\mathrm{pH}$ values were recorded than in roof-collected rainwater. The contact of rainwater with ceramic or concrete surface (ceramic roof tiles or concrete roof tiles) had a positive impact on its $\mathrm{pH}$ ( $\mathrm{pH}$ values increased).

- Micro-biological pollution of roof-harvested rainwater do not allow for its safe utilization as potable water or as water

15 intended to come into contact with food, nor for hygienic purposes. The $\mathrm{pH}$ needs to be corrected and the turbidity and faecal bacteria need to be removed.

- The analysed rainwater types can be used as resources where lower water quality is sufficient, i.e. for cleaning, car washing, laundry, toilet flushing, watering crops and lawns without any negative impact on plants or organisms living in the soil.

- The analysed rainwater types can be used as an alternative source of drinking water and for hygienic purposes in crisis 20 conditions, only after having undergone a disinfection.

\section{References}

Bai, L., Wang, Z.: Antropogenic influence on rainwater in the Xi'an City, Northwest China: Constrains from sulfur isotope and trace elements analyses, J Geochem Explor., 137, 65-72, 2014.

Basinger, M., Montalto, F., Lall, U.: A rainwater harvesting system reliability model based on nonparametric stochastic rainfall generator, J Hydrol, 392, 105-118, 2010.

Cho, B.C., Hwang, C.Y.: Prokaryotic abundance and 16S rRNA gene sequences detected in marine aerosols on the East Sea (Korea). FEMS Microbiol. Ecol. 76, 327-341, 2011.

Despins, C., Farahbakhsh, K., Leidl, C., 2009. Assessment of rainwater quality from rainwater harvesting systems in Ontario, Canada. J. Water Supply: Res.Technol. - AQUA 58, 117-134. http://dx.doi.org/10.2166/aqua.2009.013

Ding, Q., Schweige,r A., L’Heureux, M., Battisti, D., Po-Chedly, S., Jonshon, N., Blanchard - Wrigglesworth, E., Harnos, K., Zhang, Q., Estman, R., Steig, E.: Influence of high-latitude atmospheric circulation changes on summertime Arctic sea ice, Nat. Clim. Change., 7, 289-295, 2017. 
Hydrol. Earth Syst. Sci. Discuss., https://doi.org/10.5194/hess-2019-117

Manuscript under review for journal Hydrol. Earth Syst. Sci.

Discussion started: 29 April 2019

Dobrowsky,P.H., DeKwaadsteniet,M., Cloete,T.E., Khan,W.:Distribution of indigenous bacterial pathogens and potential pathogens associated with roof-harvested rainwater. Appl. Environ. Microbiol. 80, 2307-2316, http://dx.doi.org/10.1128/AEM.04130-13, 2014.

Ducan, H. P.: A review of urban stormwater quality processes, Cooperative Research Centre fo Catchment Hydrology, Melbourne, Australia, ISBN 1-876-00606-4, 1995.

Ekstrom, S., Noziere, B., Hultberg, M., Alsberg, T., Magner, J., Nilsson, E.D., Artaxo, P.,. A possible role of ground-based microorganisms on cloud formation in the atmpsphere. Biogeosciences, 7, 387-394, 2010.

Evans, C.A., Harrison, T., Coombes, P.J., Dunstan, H.R., Dunstan, R.H.: Identifying the major influences on the microbial composition of roof harvestedrainwater and the implications for water quality. In: Delectic, A., Fletcher, T. (Eds.), 7th International Conference on Urban Drainage Modelling and the4th International Conference on Water Sensitive Urban Design; Book of Proceedings, Monash University, 2006, pp. 245-252. ISBN 0-646-45903-1, 2006.

Friedler, E., Gilboa, Y., Muklada H.: Quality of Roof-Harvested Rainwater as a Function of Environmental and Air Pollution Factors in a Coastal Mediterranean City (Haifa, Israel), Water, 9, 1-12, DOI: 10.3390/w9110896, 2017.

Gikas Georgios, D., Tsihrintzis Vassilios, A.: Assesment of water quality of first - flush roof runoff and harvested rainwater. J Hydrol, 2012.

Gikas, G.D., Tsihrintzis, V.A., Assessment of water quality of first-flush roof runoff and harvested rainwater. J. Hydrol. 466467, 115-126. http://dx.doi.org/10.1016/j.jhydrol.2012.08.020, 2012.

Gunawardena, J., Egodawatta, P., Ayoko, G.A., Goonetilleke, A.: Atmospheric deposition as a source of heavy metals in urban stormwater, Atmos.Environ. 68, 235-242. http://dx.doi.org/10.1016/j.atmosenv.2012.11.062, 2013

Gwezi, W., Dunjana, N., Pisa, C., Taur,o T., Nyamadzawo, G.: Water quality nad public health risks associated with roof rainwater harwesting systems for potable supplay: review and perspectives, Sustainability of Water Quality and Ecology, 6, 107-118, 2015.

Jones, M. P., Hunt, W. F.: Performance of rainwater harvesting systems in the southeastern United States, 54, 623-629, https://doi.org/10.1016/j.resconrec.2009.11.002, 2010.

Khan, S. T. Baksh, A. A. Papon Muhammad Ashraf Ali, M. T. I.: Rainwater harvesting system: An approach for optimum tank size design and assessment efficiency, Int. J. Environ. Sci. Technol., 8, 37-43, DOI: 10.18178/ijesd.2017.8.1.917, 2017.

Kimani M. W., Gitau N. A., Ndunge D.: Rainwater Harvesting Technologies in Makueni County, Kenya, Int J Eng Sci 5, 3949, 2015.

Korzeniewska, E., Filipowska, Z., Gotkowska - Płachta, A., Janczukowic,z W., Ritkowski, B., Bacteriological pollution of the atmospheric air at the municipial and dairy Wasterwater Treatment Plant area and in its surroundings, 2008.

5 Koszelnik, P.: Atmospheric deposition as a source of nitrogen and phosphorus loads into the Rzeszow reservoir, SE Poland. Environ Prot Eng, 33, 157-164, 2007.

Kundzewicz, Z.W., Zalewski, M., Kędziora, A., Pierzgalski, E.: Zagrożenia związane z wodą, Nauka, 4, 87-96, 2010. 
Hydrol. Earth Syst. Sci. Discuss., https://doi.org/10.5194/hess-2019-117

Manuscript under review for journal Hydrol. Earth Syst. Sci.

Discussion started: 29 April 2019

Lai, Y.H., Ahmad, Y., Yusoff, I., Bong, C.W., Kong, S. Y.: Effects of roof pitch gradient and material to harvested rainwater quality, OP Conference Series Materials Science and Engineering 401, DOI: 10.1088/1757-899X/401/1/012011, 2018.

Lee, J. Y., Yang, J-S, Han, M., Choi, J.: Comparison of the microbiological anh chemical characterization of harvested rainwater and reservoir water as alternative water resources. Sci Total Environ, 2010.

5 Lee, J.Y., Bak, G., Han, M.: Quality of roof - harvested rainwater - Comparison of different roofing materials, Environ. Pollut., 162, 422-429, 2012.

Lee, M., Tansel, B., Balbin, M. Influence of residential water use efficiency measures on houshold water dem and: A four year longitudinal study. Resour Conserv Recycl., 56, 1-6, doi:10.1016/j.resconrec.2011.08.006. 2011.

Leong, J., Oh, K., S., Poh, P. E., Chong, M. N.: Prospects of hybrid rainwater-greywater decentralised system for water

10 recycling and reuse: A review, J Clean Prod, 142, 3014-3027, doi.org/10.1016/j.jclepro.2016.10.167, 2017

Ludwińska, A., Paduchowska, J.: Wykorzystanie wody deszczowej w instalacjach sanitarnych budynków, Rynek Instalacyjny, 5, 42-46, 2017.

Mendez, C. B., Klenzendorf, J.B., Afshar, B.R., Simmons, M.T., Barrett, M.E., Kinney, K.A., Kirisits, M.J.: The effect of roofing material on the quality of harvested Rainwater, Water Res., 45, 2049 -2059, 2011.

15 Naddeo, V., Scannapieco, D., Belgiorno, V.: Enhanced drinking water supply through harvested rainwater treatment, J hydrol., 498, 287-291, 2013.

Pierzgalski, E., Tyszka, J., Stolarek, A.: Powodzie i susze w lasach, Seria: Monografie IMGW-PIB, IMGW, Warszawa, 3, 243-255, 2012.

Polymenakou, P. N.: Atmosphere: A Source of Pathogenic or Beneficial Microbes?, Atmosphere, 3, 87-102,

20 https://doi.org/10.3390/atmos3010087, 2012.

Słyś, D., Stec, A.: Analiza LCC wariantów zagospodarowania wód deszczowych w budynku wielorodzinnym, Proceerings of ECOpole 2012, DOI: 10.2429/proc., 6.(1).057. 2012.

Słyś, D.: Zrównoważone systemy odwodnienia miast, Dolnośląskie Wydawnictwo Edukacyjne, Wrocław, 2013

Śmigielska, M.: Zoonoses transmitted by birds, Undomesticated, Ornis Polonica, 51, 149-162, 2010.

25 Turkum, A., Peke,y H., Tuncel, G.: Investigating relationships between aerosol and rainwater compositions at different locations in Turkey, Atmos Res, 89, 315-323, 2008.

Vialle,C., Sablayrolles,C., Lovera,M., Huau,M.C., Jacob,S., Montrejaud-Vignoles,M.: Monitoring of water quality from roof runoff: Interpretation using multivariate analysis. Water Res. 45, 3765-3775, http://dx.doi.org/10.1016/j.watres.2011.04.029, 2011.

30 Xu ZF, Wu Y, Liu WJ, Liang CS, Ji JP, Zhao T, Zhang X.: Chemical composition of rainwater and the acid neutralizing effect at Beijing and Chizhou city, China, Atmos Res, 164-165, 278-285, 2015.

Yaziz, M. I., Gunting, H., Sapari, N., Ghazali, A.: Variations in rainwater quality from roof catchments, Water Res, 23, 761$765,1989$. 
Hydrol. Earth Syst. Sci. Discuss., https://doi.org/10.5194/hess-2019-117

Manuscript under review for journal Hydrol. Earth Syst. Sci.

Discussion started: 29 April 2019

(c) Author(s) 2019. CC BY 4.0 License.

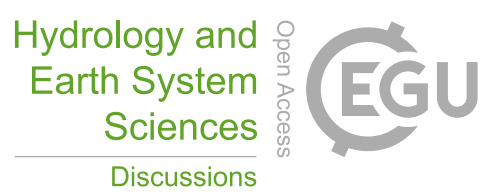

(c) (i)

Zdeb, M., Zamorska, J., Papciak, D.: Studying microbiology of rain water for of their use in economy, J. Ecol. Eng., 17, 203208, DOI: 10.12911/22998993/63314, 2016.

Zhang, Q., Wang, X., Hou, P., Wan, W., Li, R.: Quality and seasonal variation of rainwater harvested from concrete, asphalt, ceramic tile and green roofs in Chongquing, China, J Environ Manage, 132, 178-187, 2014.

5 Zhang, Y., Grant, A., Sharma, A., Chen, D., Chen, L.: Alternative Water Resources for Rural Residental Development In Western Austarlia. Water Resour Manage., 24, 25-36, doi:10.1007/s11269-009-9435-0, 2010. 